\title{
Endobronchial treatment of benign endobronchial neoplasms: Our 10 years of experience
}

\author{
Benign endobronşiyal tümörlerin endobronşiyal tedavisi: 10 yıllık deneyimimiz \\ Demet Turan' ${ }^{\circledR}$, Mehmet Akif Özgül' ${ }^{\circledR}$, Ekrem Cengiz Seyhan' ${ }^{\circledR}$, Efsun Uğur Chousein' ${ }^{\circledR}$, \\ Güler Özgül ${ }^{2}$ (D) Erdoğan Çetinkaya' ${ }^{10}$ \\ Institution where the research was done: \\ University of Health Sciences, Yedikule Chest Diseases and Thoracic Surgery Training and Research Hospital, Istanbul, Turkey
}

Author Affiliations:

'Department of Chest Disease, University of Health Sciences, Yedikule Chest Diseases and Thoracic Surgery Training and Research Hospital, Istanbul, Turkey ${ }^{2}$ Department of Chest Disease, University of Health Sciences, Bağcllar Training and Research Hospital, İstanbul, Turkey

\begin{abstract}
Background: The aim of the study was to assess the safety, efficacy, complications, and long-term outcomes of endobronchial treatment for benign endobronchial tumors.

Methods: A total of 53 patients (39 males, 14 females; mean age: 53.7 years; range, 12 to 83 years) with the diagnosis of benign endobronchial neoplasms in our center between November 2010 and September 2019 were retrospectively analyzed. Data including demographic and clinical characteristics of the patients and treatment outcomes were examined.

Results: Tumors regressed in all patients with argon plasma coagulation, diode laser and electrocautery, which was combined with cryotherapy in some cases. Complications were observed in five (9\%) patients. Major complications were atrial fibrillation in two patients and respiratory failure requiring mechanical ventilation in one patient. Minor complications were minimal bleeding in two patients. The response was very good in 39 (74\%) patients and good in $12(23 \%)$ patients. There was no significant difference in the residual tissue formation requiring cryotherapy among the endobronchial treatment modalities ( $\mathrm{p}>0.05$ ). The five-year survival rate was $94 \%$. No endobronchial treatment-related mortality was observed in any of the patients.
\end{abstract}

Conclusion: Endobronchial treatment modalities including diode laser, electrocautery, and argon plasma coagulation combined with or without cryotherapy are effective and safe in the treatment of benign endobronchial tumors.

Keywords: Argon plasma coagulation, cryotherapy, diode laser, endobronchial benign tumor, electrocautery.

\section{$\ddot{O} Z$}

Amaç: $\mathrm{Bu}$ çalışmada benign endobronşiyal tümörleri olan hastalarda endobronşiyal tedavinin güvenliliği, etkinliği, komplikasyonları ve uzun dönem sonuçları değerlendirildi.

Çalışma planı: Kasım 2010 - Eylül 2019 tarihleri arasında merkezimizde benign endobronşiyal tümör tanısı konulan toplam 53 hasta (39 erkek, 14 kadın; ort. yaş: 53.7 yıl; dağılım, 12-83 yıl) retrospektif olarak incelendi. Hastaların demografik ve klinik özellikleri ve tedavi sonuçları dahil olmak üzere veriler değerlendirildi.

Bulgular: Bazı hastalarda kriyoterapi ile birlikte kullanılmakla birlikte, diyot lazer, argon plazma koagülasyonu ve elektrokoter ile tüm hastalarda tümör gerilemesi sağlandı. Beş hastada (\%9) komplikasyon izlendi. Majör komplikasyonlar iki hastada atriyal fibrilasyon ve bir hastada mekanik ventilasyon gerektiren solunum yetmezliği idi. Minör komplikasyonlar ise, iki hastada minimal kanama idi. Yanıt 39 hastada (\%74) çok iyi ve 12 hastada (\%23) iyi idi. Endobronşiyal tedavi yöntemleri arasında kriyoterapi gerektiren rezidüel doku oluşumu açısından anlamlı bir fark yoktu $(\mathrm{p}>0.05)$. Beş yıllık sağkalım oranı \%94 idi. Hastaların hiçbirinde endobronşiyal tedavi ile ilişkili mortalite izlenmedi.

Sonuç: Kriyoterapi ile birlikte veya olmaksızın, diyot lazer, elektrokoter ve argon plazma koagülasyonu dahil olmak üzere endobronşiyal tedavi yöntemleri, benign endobronşiyal tümörlerin tedavisinde etkili ve güvenlidir.

Anahtar sözcükler: Argon plazma koagülasyon, kriyoterapi, diyot lazer, endobronşiyal benign tümör, elektrokoter.

Received: February 09, 2020 Accepted: April 06, 2020 Published online: January 13, 2021

Correspondence: Ekrem Cengiz Seyhan, MD. SBÜ Yedikule Göğüs Hastalıkları ve Göğüs Cerrahisi Eğitim ve Araştırma Hastanesi Göğüs Hastallkları Kliniği, 34020 Zeytinburnu, İstanbul, Türkiye

Tel: +90 505 - 2654417 e-mail: drekremcs@yahoo.com

Cite this article as:

Turan D, Özgül MA, Seyhan EC, Uğur Chousein E, Özgül G, Çetinkaya E. Endobronchial treatment of benign endobronchial neoplasms: Our 10 years of experience. Turk Gogus Kalp Dama 2021:29(1):61-69 
Benign endobronchial tumors are rare type of all lung tumors (2 to $5 \%$ ), which is also very rarely located in endobronchial system $(6 \%) \cdot{ }^{[1]}$ These tumors usually grow slowly and present with obstruction of the bronchi. Most patients present with symptoms and findings such as, wheezing, cough, or recurrent pneumonia. Patients are often wrongly diagnosed as having asthma and, consequently, the tumors remain undetected for years. ${ }^{[2-4]}$ Although these tumors are in benign nature, they may cause airway obstruction. Tumor removal may relieve respiratory symptoms by dilating and securing the airway. A just-in-time diagnosis and endobronchial treatment of these tumors allow a successful conservative treatment with improved patient outcomes. ${ }^{[5]}$

The choice between surgical and endobronchial treatment is made based on the characteristics of the patient's medicalcondition and the tumor.Endobronchial tumors connected to the tracheobronchial surface with a large base are not suitable for bronchoscopic removal and require surgical resection. ${ }^{[6]}$ However, tumors localized in the proximal sections of the tracheobronchial tree are suitable for bronchoscopic procedures. ${ }^{[6]}$ For these patients, therapeutic bronchoscopy (argon plasma coagulation [APC], laser vaporization, cryotherapy, and electrocautery) provides rapid palliation that can be life-saving and improve quality of life.

Due to the uncommon occurrence of these tumors, there are not many randomized studies regarding the use of endobronchial treatment and options. In this study, we aimed to evaluate our institutional experience with different endobronchial treatment methods for benign tracheobronchial tumors and follow-up bronchoscopic findings.

\section{PATIENTS AND METHODS}

This single-center, retrospective study was conducted at the Respiratory Endoscopy Unit of Yedikule Chest Diseases and Thoracic Surgery Training and Research Hospital between November 2010 and September 2019. The databases of our center were retrospectively searched for the records of benign endobronchial lung tumors treated with endobronchial treatment. Data including clinical diagnosis, bronchoscopy findings, treatment modalities, success of treatment modalities, duration of follow-up, and survival time were retrieved from the database. Before endobronchial treatment, a written informed consent was obtained from each patient and/or parent outlining all potential risks including airway perforation, infection, and death.
A total of 53 patients ( 39 males, 14 females; mean age: 53.7 years; range, 12 to 83 years) were included in the study. The study protocol was approved by the Institutional Review Board approval (IRB Committee A; 3.4.2019. 218/7). The study was conducted in accordance with the principles of the Declaration of Helsinki.

Endobronchial benign tumors were managed primarily by a core-out of the tumor using the neodymium-doped yttrium aluminum garnet (Nd:YAG) laser, electrocautery, and APC as adjuncts to mechanical debridement and subsequent retrieval of the debrided mass with the help of telescope-enabled biopsy forceps and cryotherapy. Rigid bronchoscopy (RB) was performed under general anesthesia in the operating room. The patients were intubated by an RB (Efer Endoscopy, La Ciotat, France) using standard techniques. The equipment used included the Dumon ${ }^{\mathrm{TM}}$ Series II rigid bronchoscopes (Efer Endoscopy, La Ciotat, France) with the optical system. The APC (40 W, blended mode/continuous flow) was applied using an instrument by the ERBOKRYO system (Erbe Elektromedizin GmbH, Tübingen, Germany). Endoluminal treatment was accomplished with a diode laser operating at a wavelength of $980 \mathrm{~nm}$ with 4 to $25 \mathrm{~W}$ in the pulsed mode (Ceralas ${ }^{\circledR} \mathrm{D} 25$; Biolitec $\mathrm{GmbH}$, Jena, Germany). Cryotherapy was performed with the ERBOKRYO ${ }^{\circledR}$ system (Elektromedizin GmbH, Tübingen, Germany).

The primary outcome measures were the response to treatment (clinical success), and the complications of the endobronchial treatment. All hypoxemia, any respiratory insufficiency needing mechanical ventilation, arrhythmia, hemorrhage, trauma, and death within $24 \mathrm{~h}$ following the procedure were defined as complications. Total number of procedures for endobronchial treatment, tumor recurrence, and rate of residual disease were also evaluated. The response to endobronchial treatment was classified as very good, when complete removal of the tumor was possible at the first session of endobronchial treatment. If the tumor could be partially removed or repeated sessions were needed, the response to endobronchial treatment was classified as good. A poor response was denoted that the tumor could not be removed with endobronchial treatment. ${ }^{[7]}$

\section{Statistical analysis}

Statistical analysis was performed using the $\mathrm{R}$ free software (R Development Core Team, 2014). Descriptive data were expressed in mean \pm standard 
deviation (SD), median (min-max) and number and frequency. The Student's t-test and one-way analysis of variance (ANOVA) tests were used to compare the mean values and the Mann-Whitney $U$ test was used to compare median values. The chi-square and Fisher's exact test were used to compare frequencies. The Spearman and Pearson correlation tests were applied for correlation analysis. On survival analysis, the time when the patients were recruited was defined as zero-day, while the last time of follow-up or date of mortality was considered as the final day. The KaplanMeier survival analysis was performed for univariate survival analysis. The log-rank or Cox tests were used to compare survival rates. A $p$ value of $<0.05$ was considered statistically significant.

\section{RESULTS}

The majority of the patients $(64 \%)$ had greater than $75 \%$ narrowing of the airway. The locations of the tumors were as follows: 16 were located in the trachea $(30 \%), 13$ in the right main bronchus (25\%), and 11 in the left main bronchus (21\%) (Table 1).

A total of 67 endobronchial treatment procedures were successfully employed in all patients. The APC treatment was the most preferred modality of endobronchial treatment in 24 (45\%) patients. Endobronchial treatment resulted in a rapid improvement of symptoms in $92 \%$ patients (49/53). Thirty-nine $(74 \%)$ patients had a very good response (Figure 1a-d) and 12 (23\%) patients had a good

Table 1. Demographic and clinical data of patients $(n=53)$

\begin{tabular}{|c|c|c|c|}
\hline Variables & $\mathrm{n}$ & $\%$ & Mean \pm SD \\
\hline Age (year) & & & $53.7 \pm 14.3$ \\
\hline \multicolumn{4}{|l|}{ Sex } \\
\hline Male & 39 & 74 & \\
\hline \multicolumn{4}{|l|}{ Comorbidities } \\
\hline Diabetes mellitus & 3 & 6 & \\
\hline Cardiovascular disease & 2 & 4 & \\
\hline Cerebrovascular disease & 1 & 2 & \\
\hline Chronic pulmonary disease & 1 & 2 & \\
\hline Others* & 3 & 6 & \\
\hline \multicolumn{4}{|l|}{ Symptoms } \\
\hline Dyspnea & 36 & 68 & \\
\hline Cough & 34 & 64 & \\
\hline Wheezing & 6 & 11 & \\
\hline Hemoptysis & 4 & 7 & \\
\hline Constitutional symptoms & 4 & 7 & \\
\hline \multicolumn{4}{|l|}{ Endobronchial bening tumor type } \\
\hline Hamartoma & 17 & 32 & \\
\hline Lipoma & 8 & 15 & \\
\hline Fibroepithelial polyp & 8 & 15 & \\
\hline Amyloidosis & 4 & 7 & \\
\hline Chondroma & 4 & 7 & \\
\hline Hemangioma & 4 & 7 & \\
\hline Inflammatory pseudopolyp & 2 & 4 & \\
\hline Papilloma & 2 & 4 & \\
\hline Tracheobronchopathia osteochondroplastica & 2 & 4 & \\
\hline Ectopic parathyroid adenoma & 1 & 2 & \\
\hline Heterotopic thyroid adenoma & 1 & 2 & \\
\hline \multicolumn{4}{|l|}{ Locations of the endobronchial benign tumor } \\
\hline Trachea & 16 & 30 & \\
\hline Right main bronchus & 13 & 25 & \\
\hline Left main bronchus & 11 & 21 & \\
\hline Lobar bronchi & 9 & 17 & \\
\hline Multiple locations & 4 & 7 & \\
\hline
\end{tabular}

SD: Standard deviation; * Chronic renal disease $(n=1)$, Rheumatoid arthritis $(n=1)$, Chronic hepatitis $(n=1)$. 

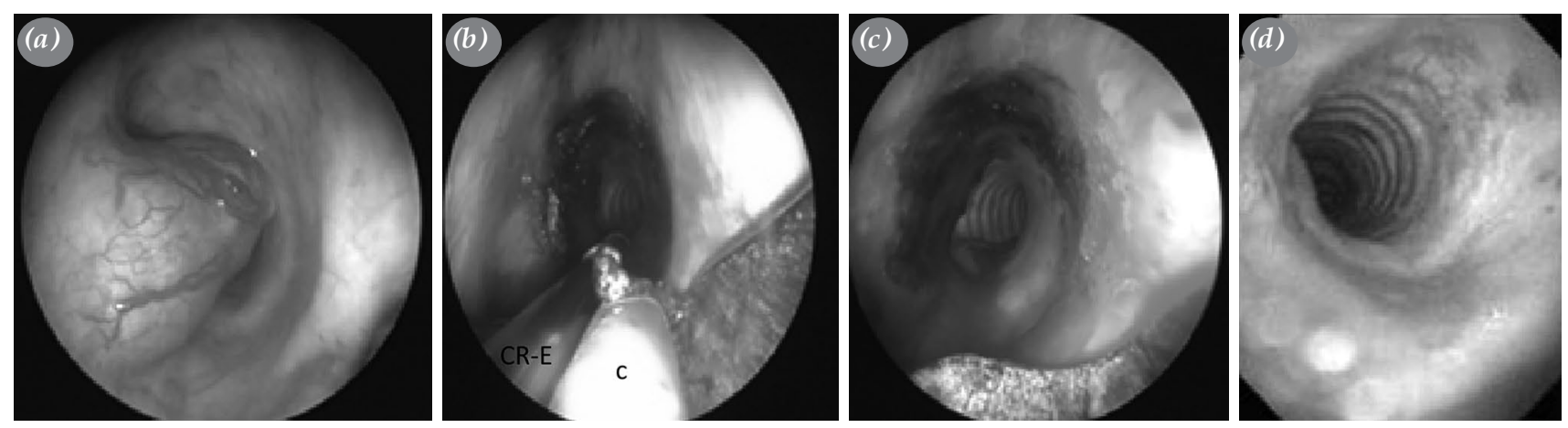

Figure 1. Rigid bronchoscopic view of heterotopic thyroid adenoma. (a) A pinkish colored vascularized mass originating from left posterolateral wall of trachea approximately 1 to $1.5 \mathrm{~cm}$ after cord vocals, obliterating lumen by $90 \%$. (b) Mass removal by using argon plasma coagulation and cryoextraction. (c) A view of bronchial lumen after removal of mass. (d) Bronchoscopic appearance one month after endobronchial treatment.
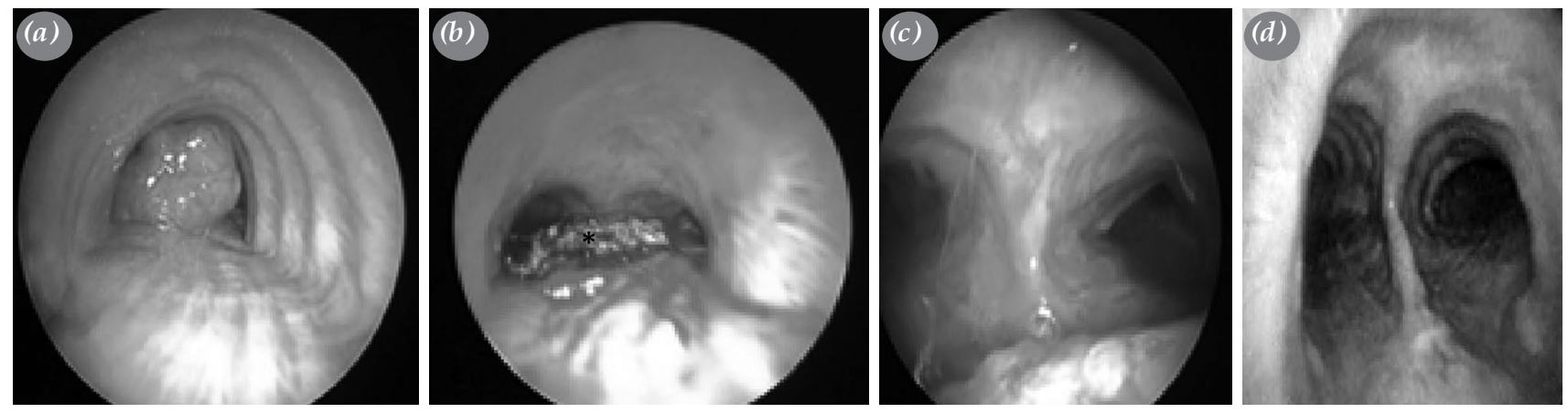

Figure 2. Rigid bronchoscopic view of hamartoma. (a) Lobulated lesion originating from posterior wall of carina in distal trachea, obliterating lumen by $80 \%$, continuing into right bronchus. (b) Mass removal by using argon plasma coagulation and cryoextraction and, then, the remaining residual tissue (asterisk) cryotherapy. (c) A view of bronchial lumen after removal of the mass. (d) Bronchoscopic appearance 10 month after endobronchial treatment.
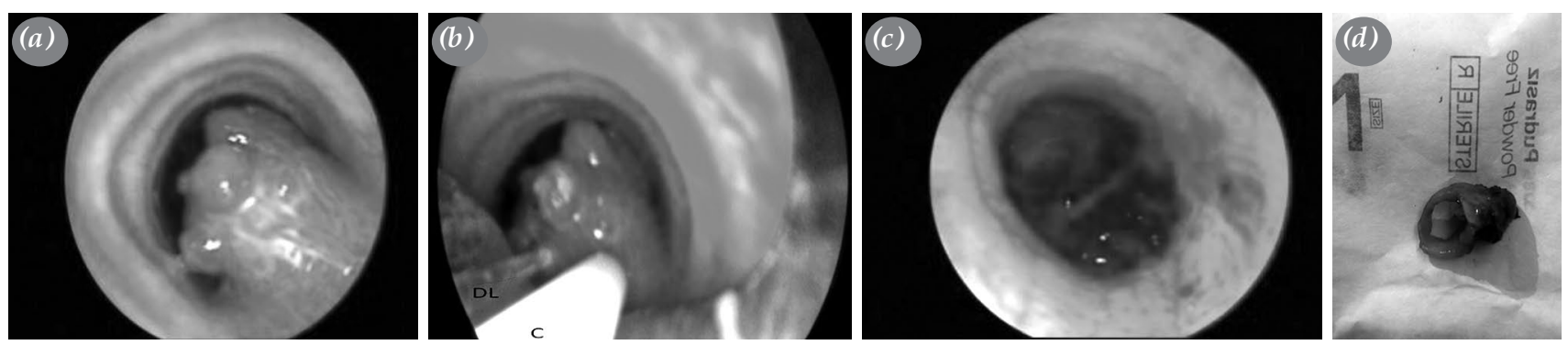

Figure 3. Rigid bronchoscopic view of ectopic parathyroid adenoma. (a) A vegetating polypoid lesion which was constricting $80 \%$ of distal part of tracheal lumen. (b) The mass was treated by DL photoresection, and debris was removed by a biopsy catheter and, then, the remaining residual tissue was removed by cryotherapy. (c) View of bronchial lumen after the removal of the mass. (d) Surgery decision was made for the remaining tissue removal and a 4-cm long trachea segment was resected with the tumor.

DL: Diode laser; C: Catheter.

response (Figure 2a-d). Two (4\%) patients had a poor response and these patients were referred to surgical procedures (Table 2).

The median follow-up was 65 (36-79) mouths. After endobronchial treatment, residual tumor tissue was detected in 13 patients (25\%). Cryotherapy was applied to these cases. There were no significant differences among APC, electrocautery, and laser treatments in terms of residual tissue formation requiring cryotherapy ( $>0.05)$ (Table 3). 


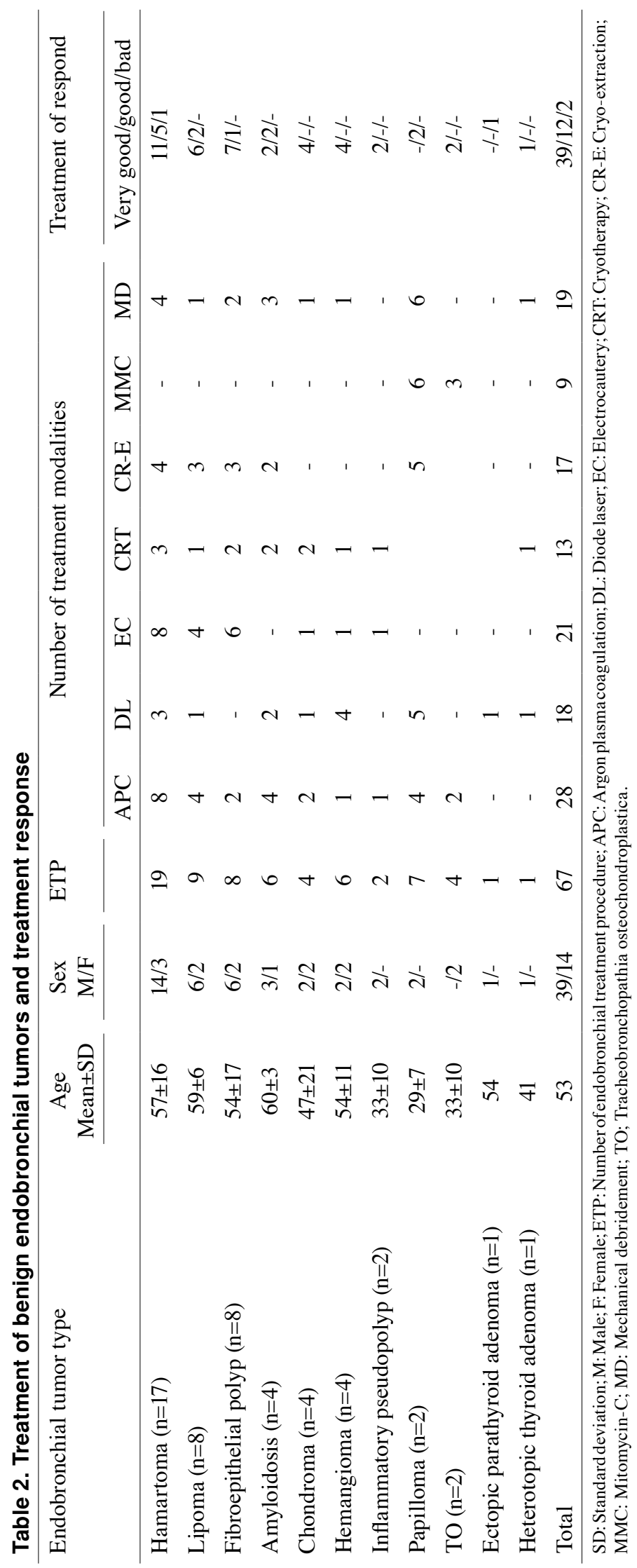


Table 3. Comparison of treatment modalities according to the need for cryotherapy to residual neoplasms

\begin{tabular}{lccc}
\hline & & \multicolumn{2}{c}{ Cryotherapy } \\
\cline { 3 - 4 } Endobronchial treatment modalities & $\mathrm{n}$ & $\mathrm{n}$ & $\%$ \\
\hline Group 1 & 24 & 6 & 25 \\
Group 2 & 12 & 3 & 25 \\
Group 3 & 17 & 4 & 23 \\
& Group 1 and Group 2 & $\mathrm{NS}$ & \\
Statistical evaluation (p values) & Group 1 and Group 3 & $\mathrm{NS}$ & $\mathrm{NS}^{+}$ \\
& Group 2 and Group 3 & $\mathrm{NS}$ & \\
\hline
\end{tabular}

Group 1: Argon plasma coagulation treatment modalities group; Group 2, diode laser treatment modalities group; Group 3: Electrocautery treatment modalities group; NS: Statistically nonsignificant; + One-way ANOVA tests.

Complications were recorded in five $(9 \%)$ patients. Major complications were atrial fibrillation in two (4\%) patients which was controlled medically and respiratory failure requiring two days of mechanical ventilation support in one $(2 \%)$ patients. Minor complication was minimal bleeding in two (4\%) patients. Two patients with hamartoma and ectopic parathyroid adenoma diagnosis were referred to surgery (Figure 3a-d). No recurrence was observed during five years of follow-up. The five-year survival rate was $94 \%$ in the patients with benign endobronchial neoplasms (Figure 4). Three (6\%) of

Table 4. Complications and follow-up results

\begin{tabular}{|c|c|c|c|c|}
\hline Variables & $\mathrm{n}$ & $\%$ & Median & Interquartile range \\
\hline Complications & 5 & 9 & & \\
\hline Excessive bleeding & - & - & & \\
\hline Minimal-moderate bleeding & 2 & 4 & & \\
\hline Atrial fibrillation & 2 & 4 & & \\
\hline Respiratory distress needing MV & 1 & 2 & & \\
\hline Procedure-related death & - & - & & \\
\hline Presence of residual tumor & 13 & 24 & & \\
\hline Hamartoma & 3 & 5 & & \\
\hline Chondroma & 2 & 4 & & \\
\hline Fibroepithelial polyp & 2 & 4 & & \\
\hline Amyloidosis & 2 & 4 & & \\
\hline Lipoma & 1 & 2 & & \\
\hline Hemangioma & 1 & 2 & & \\
\hline Papilloma & 1 & 2 & & \\
\hline Ectopic parathyroid adenoma & 1 & 2 & & \\
\hline Recurrence & - & - & & \\
\hline Surgery & 2 & 4 & & \\
\hline Hamartoma & 1 & 2 & & \\
\hline Ectopic parathyroid adenoma & 1 & 2 & & \\
\hline Follow-up after EBTM (month) & & & 65 & $36-79$ \\
\hline Mortality ratios & 3 & 6 & & \\
\hline \multicolumn{5}{|l|}{ Causes of death } \\
\hline Amyloidosis (respiratory failure) & 1 & 2 & & \\
\hline Papillomatosis (respiratory failure) & 1 & 2 & & \\
\hline Hamartoma (secondary tumor, adenocarcinoma of lung) & 1 & 2 & & \\
\hline
\end{tabular}

MV: Mechanical ventilation, EBTM: Endobronchial treatment modality. 


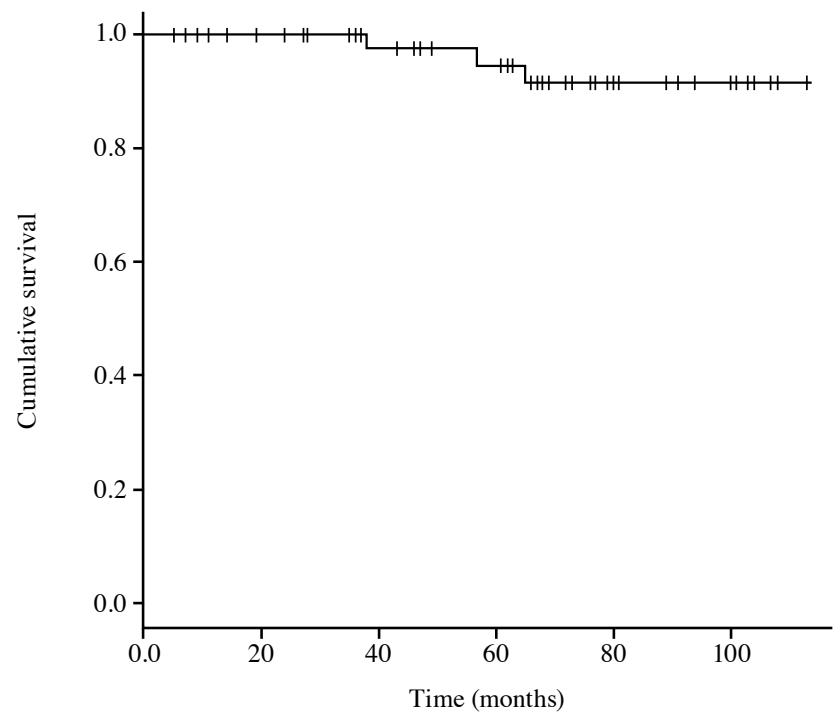

Figure 4. Kaplan-Meier plot showing survival curves of patients with endobronchial benign tumors.

53 patients died (one with amyloidosis at 38 months, one with papillomatosis at 57 months, and one with hamartoma due to a secondary tumor, adenocarcinoma of the lung at 65 months) (Table 4). There was no statistically significant factor affecting mortality in endobronchial benign tumors.

\section{DISCUSSION}

The endobronchial treatment of benign tumors in the literature can be classified in three main groups as non-randomized experiments, observational studies including case series, and retrospective comments. ${ }^{[8]}$ Neither consensus statements, nor randomized trials exist in the current literature regarding the use and selection of various bronchoscopic techniques in the management of benign endobronchial tumors, due to the rarity of these tumors. In our study, based on our 10-year retrospective data, we assessed the indications, complications, and follow-up of endobronchial treatment for endobronchial benign lung tumors and discussed them in the light of existing literature. We found that our patients met the established indications for endobronchial treatment and the majority of the patients (92\%) had symptomatic relief after endobronchial treatment. Two patients who were not symptomatically relieved due to inadequate airway patency and had extraluminal extension of the tumor were referred to surgery. In addition, there were no cases of endobronchial treatment-related mortality.

Benign endobronchial neoplasms are classified according to their origin into mesenchymal,submucosal glandular, and surface epithelial tumors. ${ }^{[9]}$ The majority of these are of mesenchymal origin, most commonly hamartomas. ${ }^{[10]}$ Tumors of the tracheobronchial tree have a slow growth rate and present with non-specific symptoms such as cough and wheezing. Patients are usually misdiagnosed as having asthma or chronic obstructive pulmonary disease and diagnosis is often delayed for months or years. ${ }^{[2]}$ In our study, similar to the results in the literature, the most common tumors were endobronchial hamartomas (32\%) and the most common symptoms were dyspnea and wheezing. In addition, $11(21 \%)$ patients and $3(6 \%)$ patients were misdiagnosed with asthma and chronic obstructive pulmonary disease, respectively.

Although bronchoscopic treatment is mostly used in the palliative treatment of malignant tracheobronchial tumors, it can be used on its own or in combination with other methods in the treatment of benign tumors. ${ }^{[11-13]}$ In general, multiple bronchoscopic treatment methods (i.e., APC, laser, and cryotherapy) are used simultaneously for the treatment of benign endobronchial tumors. Cavaliere et al. ${ }^{[13]}$ evaluated the results of the endobronchial treatment of 59 benign tumors and reported that they cured and did not recur in all cases. In another study, 20 hamartomas of 44 patients were evaluated retrospectively. ${ }^{[14]}$ Diode laser was used in 19 patients, APC was used in 16 patients, and cryotherapy was used in 13 patients. The authors reported no significant difference between the APC and laser treatment results. With the endobronchial treatment, a very good response (complete tumor removal) was achieved in $70 \%$ and a good response (partial removal of the tumor) in $30 \%$ of the cases. Surgical resection was required in two of the cases $(4.5 \%)$, as the tumor was not fully diagnosed and residual tumor remained. In our study, we used endobronchial treatment methods with instant effects, including diode laser and/or APC and/or electrocautery with or without concurrent cryotherapy. We achieved a high rate of success with endobronchial treatment modalities. In addition, a very good response (complete tumor removal) was achieved in $74 \%$ and a good response (partial removal of the tumor) in 23\% of the patients with endobronchial treatment. Surgical resection was required in only two (3\%) patients, since the tumor was not fully diagnosed and residual tumor remained. Consistent with the literature, no recurrence was observed during the follow-up period.

Endobronchial cryotherapy alone is known to be ineffective for endobronchial benign tumors. ${ }^{[8]}$ Repeated applications of cryotherapy may be needed for total lesion removal, and this can be considered 
the main disadvantage of endobronchial cryotherapy. The cryotherapy has a slow reacting mechanism of action and, therefore, it is not appropriate to use in an emerging situation. ${ }^{[15,16]}$ Nassiri et al. ${ }^{[17]}$ treated seven patients with cryotherapy in the series related to endobronchial lipomas and no recurrence was seen. Moorjani et al. ${ }^{[18]}$ reported that, in 20 benign endobronchial tumors, symptomatic improvement was achieved in all patients with cryotherapy and complete removal was achieved in 15 of 20 patients, while residual tumor was seen in five of them. In another study, the authors applied cryotherapy in combination with APC or laser to endobronchial benign tumor cases and used cryotherapy to prevent recurrence after achieving airway stability with APC or laser. ${ }^{[14]}$ In our study, cryotherapy was applied in $13(30 \%)$ patients. In this study, cryotherapy was not chosen as the first choice in endobronchial benign tumors, and it was applied to the endobronchial residual tumors after APC, electrocautery, and laser treatment. We found no significant difference in the residual tissue formation requiring cryotherapy among the use of diode laser, APC or electrocautery as treatment modalities.

The cryoextraction method is based on the evacuation of the tumor by extraction after freezing the tissue of the probe introduced into the tumor. Although the risk of bleeding during administration is low, bleeding may occur after the necrosis of the tumor tissue. Schuman et al. ${ }^{[19]}$ used APC to prevent hemorrhage and rapidly shrink the remaining tumor after the cryoextraction technique in endobronchial tumors and $12 \%$ reported mild or moderate bleeding complications requiring APC. In our study, in 17 patients, cryoextraction treatment was applied in addition to endobronchial treatment. We observed no serious bleeding complications after cryoextraction. Therefore, endobronchial cryotherapy should be safely used only in the treatment of selected patients with endobronchial benign tumors.

Review of the literature reveals a mortality rate of $0.5 \%$ following endobronchial treatment of benign tumors. ${ }^{[8]}$ Rare complications of bronchoscopic treatment include pneumomediastinum, mediastinal emphysemas, and bronchial lymph fistula, with reported rates of $0.9 \%, 1.4 \%, 1 \%$, and $0.5 \%$, respectively. ${ }^{[7,8]}$ The reported recurrence rate for endobronchial benign tumors treated with bronchoscopy is $8.4 \%$, while the rate of endobronchial benign tumors requiring surgery for residual or recurrent tumors is $5 \% .^{[6,8]}$ In the present study, all patients were cured with endobronchial treatment and no recurrences were seen during follow-up. Consistent with the literature, in our study, there was no mortality due to endobronchial treatment and the major complication rate $(6 \%)$ was low. Surgery was required for residual tumors in only two $(4.5 \%)$ patients.

The main limitation of this study is the lack of a prospective, randomized-controlled study design with a relatively small sample size. Therefore, further large-scale, prospective, controlled studies comparing endobronchial treatment with additional surgical procedures would provide more accurate results.

In conclusion, endobronchial treatment of benign tumors is an effective and safe method which can keep patients away from major procedures, such as surgery. Nevertheless, further prospective, randomized studies are needed to draw a firm conclusion on which endobronchial treatment modality should be used in benign endobronchial tumors.

\section{Declaration of conflicting interests}

The authors declared no conflicts of interest with respect to the authorship and/or publication of this article.

\section{Funding}

The authors received no financial support for the research and/or authorship of this article.

\section{REFERENCES}

1. Madan K, Agarwal R, Bal A, Gupta D. Bronchoscopic management of a rare benign endobronchial tumor. Rev Port Pneumol 2012;18:251-4.

2. Irani F, Kumar B, Reddy P, Narwal-Chadha R, Kasmani R, Tita J. An endobronchial lipoma mimicking asthma and malignancy. Prim Care Respir J 2010;19:281-3.

3. Stevic R, Milenkovic B, Stojsic J, Pesut D, Ercegovac $\mathrm{M}$, Jovanovic D. Clinical and radiological manifestations of primary tracheobronchial tumours: a single centre experience. Ann Acad Med Singap 2012;41:205-11.

4. Ko JM, Jung JI, Park SH, Lee KY, Chung MH, Ahn MI, et al. Benign tumors of the tracheobronchial tree: CT-pathologic correlation. AJR Am J Roentgenol 2006;186:1304-13.

5. Agarwal A, Agrawal A, Alagusundarmoorthy SS, Meena N. Benign endobronchial neoplasms: A review. J Pulm Respir Med 2015;5:275.

6. Kajiwara N, Kakihana M, Usuda J, Ohira T, Kawate N, Ikeda $\mathrm{N}$. Interventional management for benign airway tumors in relation to location, size, character and morphology. J Thorac Dis 2011;3:221-30.

7. Shah H, Garbe L, Nussbaum E, Dumon JF, Chiodera PL, Cavaliere S. Benign tumors of the tracheobronchial tree. Endoscopic characteristics and role of laser resection. Chest 1995;107:1744-51. 
8. Bellinger CR, Miller SM, Chin R, Chatterjee AB, Conforti JF. Therapeutic Relief of Benign Endobronchial Tumors, Clinical Pulmonary Medicine 2011;18:144-7.

9. Wilson RW, Kirejczyk W. Pathological and radiological correlation of endobronchial neoplasms: Part I, Benign tumors. Ann Diagn Pathol 1997;1:31-46.

10. Cosío BG, Villena V, Echave-Sustaeta J, de Miguel E, Alfaro J, Hernandez L, et al. Endobronchial hamartoma. Chest 2002;122:202-5.

11. Gao H, Ding X, Wei D, Cheng P, Su X, Liu H, et al. Endoscopic management of benign tracheobronchial tumors. J Thorac Dis 2011;3:255-61.

12. Sachdeva A, Pickering EM, Lee HJ. From electrocautery, balloon dilatation, neodymium-doped:yttrium-aluminumgarnet (Nd:YAG) laser to argon plasma coagulation and cryotherapy. J Thorac Dis 2015;7(Suppl 4):S363-79.

13. Cavaliere S, Foccoli P,Farina PL. Nd:YAG laser bronchoscopy. A five-year experience with 1,396 applications in 1,000 patients. Chest 1988;94:15-21.

14. Dalar L, Ozdemir C, Abul Y, Sokucu SN, Karasulu L, Urer $\mathrm{HN}$, et al. Endobronchial treatment of carcinoid tumors of the lung. Thorac Cardiovasc Surg 2016;64:166-71.

15. Bolliger CT, Mathur PN, Beamis JF, Becker HD, Cavaliere $\mathrm{S}$, Colt $\mathrm{H}$, et al. ERS/ATS statement on interventional pulmonology. European Respiratory Society/American Thoracic Society. Eur Respir J 2002;19:356-73.

16. Marasso A, Gallo E, Massaglia GM, Onoscuri M, Bernardi V. Cryosurgery in bronchoscopic treatment of tracheobronchial stenosis. Indications, limits, personal experience. Chest 1993;103:472-4.

17. Nassiri AH, Dutau H, Breen D, Colchen A, Quiot JJ, Nguyen $\mathrm{B}$, et al. A multicenter retrospective study investigating the role of interventional bronchoscopic techniques in the management of endobronchial lipomas. Respiration 2008;75:79-84.

18. Moorjani N, Beeson JE, Evans JM, Maiwand MO. Cryosurgery for the treatment of benign tracheo-bronchial lesions. Interact Cardiovasc Thorac Surg 2004;3:547-50.

19. Schumann C, Hetzel M, Babiak AJ, Hetzel J, Merk T, Wibmer T, et al. Endobronchial tumor debulking with a flexible cryoprobe for immediate treatment of malignant stenosis. J Thorac Cardiovasc Surg 2010;139:997-1000. 